EVALUASI, 4 (1), Maret 2020, ISSN 2580-3387 (print) |

ISSN 2615-2886 (online)

Homepage : http://e-journal.staima-alhikam.ac.id/index.php/evaluasi

DOI : : http://doi.org/10.32478/evaluasi.v4i1.358

Article type : Original Research Article

\title{
PENERAPAN DISIPLIN DAN DAMPAKNYA TERHADAP \\ PENGEMBANGAN DIRI DI PESANTREN HUBULO
}

\author{
Mariaty Podungge \\ Dosen Pendidikan Agama Islam IAIN Sultan Amai Gorontalo
}

\begin{abstract}
The aims of this study is to determine and analyze the impact of the application of discipline to self-development of students in the field of extracurricular. Self-development is the individual competence in educating theirself with good character which encourage to develop their potency. The method used in this research is qualitative method with naturalistic and psychological approach. The results of this study indicated that the implementation of discipline in Hubulo islamic boarding school has a positive impact on self-development of students, but in general the application of discipline applied by Hubulo islamic boarding school has not been able to improve the good results of selfdevelopment of students. This happens because the discipline implementation in Hubulo islamic boarding school is very rigid and inflexible, while the time for self-development activities is very little so that the goal of self-development of students is not achieved maximally.

Key Word : Discipline Implementation; Effect; Student Self Development.; Hubulo Islamic Boarding School
\end{abstract}

\begin{abstract}
Abstrak
Tujuan penelitian ini adalah untuk mengetahui dan menganalisis dampak dari penerapan disiplin terhadap pengembangan diri santri dalam bidang ekstrakurikuler. Pengembangan diri adalah kemampuan individu dalam mendidik dirinya sendiri dengan hal-hal yang baik, yang berpotensi untuk mendorong dirinya mengembangkan bakatnya. Penelitian ini adalah penelitian kualitatif dengan pendekatan naturalistik dan psikologis. Hasil penelitian ini menunjukkan bahwa penerapan disiplin di pesantren Hubulo memiliki dampak positif terhadap pengembangan diri santri. Secara umum penerapan disiplin di pesantren

80 Email: mariatypodungge@iaingorontalo.ac.id

EVALUASI: Jurnal Manajemen Pendidikan Islam is licensed under

The CC BY License (https://creativecommons.org/licenses/by-sa/4.0/)
\end{abstract}


EVALUASI, 4 (1), Maret 2020, ISSN 2580-3387 (print) |

ISSN 2615-2886 (online)

Homepage : http://e-journal.staima-alhikam.ac.id/index.php/evaluasi

DOI : : http://doi.org/10.32478/evaluasi.v4i1.358

Article type : Original Research Article

Hubulo belum mampu meningkatkan hasil yang baik dalam pengembangan diri santri. Hal ini terjadi karena penerapan disiplin di pesantren Hubulo tidak seimbang dengan waktu yang diperlukan untuk kegiatan pengembangan diri, sehingga tujuan dari pengembangan diri santri tidak tercapai dengan maksimal.Penerapan disiplin di pesantren Hubulo merupakan bentuk kepatuhan dan ketaatan santri dalam menjalani kehidupan sehari-hari di pesantren Hubulo. Penerapan disiplinbertujuan untuk menciptakan nuansa pembelajaran yang aman, nyaman dan kondusif.

Kata Kunci : Penerapan disiplin; Dampak; Pengembangan Diri santri.; Pesantren Hubulo

\section{A. PENDAHULUAN}

Pesantren merupakan lembaga pendidikan tradisional Islam sekaligus tempat untuk mempelajari, memahami, menghayati dan mengamalkan ajaran Islam dengan menekankan pentingnya moral keagamaan sebagai pedoman perilaku sehari-hari. ${ }^{1}$ Dalam peraturan pemerintah Republik Indonesia nomor 55 tahun 2007 tentang Pendidikan Agama dan Pendidikan Keagamaan bab I pasal I ayat 4 disebutkan, pesantren atau pondok pesantren adalah lembaga pendidikan keagamaan Islam berbasis masyarakat yang menyelenggarakan pendidikan diniyah atau secara terpadu dengan jenis pendidikan lainnya. ${ }^{2}$ Setiap individu yang menuntut ilmu di pesantren disebut santri. Santri adalah seseorang yang mengikuti seorang kyai dengan tujuan belajar darinya suatu ilmu pengetahuan agama. ${ }^{3}$ Pembelajaran di pesantren bukan hanya belajar pengetahuan akademik, akan tetapi juga belajar memaknai kehidupan di luar pesantren.

Pesantren Hubulo merupakan salah satu pesantren modern yang ada di Gorontalo. Pengembangan diri santri dalam bidang ekstrakurikuler menjadi prioritas utama setelah pelajaran formal. Pendidikan di pesantren

\footnotetext{
${ }^{1}$ Zamakhsyari Dhofier, Tradisi Pesantren: Studi Tentang Pandangan Kiai (Jakarta: LP3ES, 1982).

2 Departemen Agama RI, Pendidikan, Kumpulan Undang-Undang Dan Peraturan Pemerintah RI Tentang (Jakarta: Direktorat Jenderal Pendidikan Departemen Agama RI, 2006).

${ }^{3}$ Edi Suharto, Membangun Masyarakat Memberdayakan Rakyat Kajian Strategis Pembangunan Kesejahteraan Sosial Dan Pekerjaan Sosial (Bandung: PT Reflika Aditama, 2005).
} 
EVALUASI, 4 (1), Maret 2020, ISSN 2580-3387 (print) |

ISSN 2615-2886 (online)

Homepage : http://e-journal.staima-alhikam.ac.id/index.php/evaluasi

DOI : : http://doi.org/10.32478/evaluasi.v4i1.358

Article type : Original Research Article

Hubulo menerapkan sistem kedisiplinan yang tinggi. Penegakkan disiplin santri merupakan sistem yang harus dijalankan dalam proses menghasilkan alumni yang baik dan berkualitas. Disiplin yang diterapkan tidak terbatas pada pelajaran formal saja, akan tetapi juga berlaku pada pembelajaran yang bersifat non formal terutama kegiatan ekstrakurikuler. Penerapan disiplin di pesantren yang memberikan kesempatan kepada santri untuk menempuh pendidikan tiga sampai enam tahun memiliki tujuan tertentu. Menurut Charles, tujuan disiplin ada 2, yaitu: 1). Tujuan jangka pendek yaitu supaya santri terlatih dan terkontrol dengan ajaran yang pantas; dan 2). Tujuan jangka panjang yaitu untuk mengembangkan dan pengendalian diri santri tanpa pengaruh pengendalian dari luar. ${ }^{4}$ Terlatih dan terkontrol merupakan bagian dari proses sehingga ketika santri mampu menjalankan disiplin dengan baik maka santri menjadi pribadi yang teguh tanpa ada pengaruh dari orang lain. Penerapan disiplin juga dapat membentuk karakter santi karena waktu berkesinambungan yang ada. menurut Ariesandi, disiplin adalah proses melatih pikiran dan karakter santri secara bertahap sehingga menjadi seseorang yang memiliki kontrol diri dan berguna bagi masyarakat. ${ }^{5}$ Dengan penerapan disiplin, diharapkan bakat santri dapat berkembang secara maksimal.

Bakat santri yang diasah sejak awal masuk pesantren dapat diasah menjadi keterampilan dan bekal menghadapi era globalisasi. Peran santri di masa depan di asah sejak menempuh pendidikan di pesantren agar dapat memberikan prestasi Hal ini juga sebagai solusi untuk menghadapi problematika pendidikan pondok pesantren. ${ }^{6}$ Mengasah bakat dalam pengembangan diri juga berupa pendidikan keterampilan yang dilakukan karena sebagai salah satu upaya kiyai dalam meningkatkan pendidikan agama Islam. ${ }^{7}$ Oleh karena itu pengembangan diri diharapkan memberikan manfaat untuk pribadi itu sendiri.

${ }^{4}$ Charles Schaefer, Cara Efektif Mendidik Dan Mendisiplinkan Anak (Jakarta: Mitra Utama, 1980).

${ }^{5}$ Ariesandi, Rahasia Mendidik Anak Agar Sukses Dan Bahagia (Jakarta: PT. Gramedia Utama, 2008).

6 - Ja'far, 'Problematika Pendidikan Pondok Pesantren Di Era Globalisasi', Journal EVALUASI, 2.1 (2018), 350 <https://doi.org/10.32478/evaluasi.v2i1.83>.

${ }^{7}$ Miftakhul Munir, 'MANAJEMEN PESANTREN DALAM MENINGKATKAN PENDIDIKAN AGAMA ISLAM DI PONDOK PESANTREN AL-AMIN NGASINAN REJOMULYO KEDIRI', 
EVALUASI, 4 (1), Maret 2020, ISSN 2580-3387 (print) I

ISSN 2615-2886 (online)

Homepage : http://e-journal.staima-alhikam.ac.id/index.php/evaluasi

DOI : : http://doi.org/10.32478/evaluasi.v4i1.358

Article type : Original Research Article

Pengembangan diri adalah kegiatan di luar mata pelajaran sekolah dan merupakan bagian yang tidak terpisahkan dari kurikulum sekolah dengan tujuan membentuk watak santri melalui kegiatan pelayanan konseling serta kegiatan ekstrakurikuler, untuk mengembangkan potensi diri santri secara optimal, sehingga menjadi manusia yang mampu menjawab berbagai tantangan yang datang dari dirinya sendiri maupun lingkungannya secara adaptif dan konstruktif. ${ }^{8}$ Lingkungan di Pesantren sbagai sekolah berasrama mendudkung setiap pribadi santri untuk terbiasa dengan lingkungan yang mengasah potensi diri. Pengembangan diri adalah usaha yang dilakukan oleh individu untuk mendidik dirinya sendiri dengan hal-hal yang baik dengan tujuan mendorong dirinya untuk mampu beraktualisasi secara maksimal. ${ }^{9}$ Pengembangan diri bertujuan mengembangkan potensi santri secara optimal, yaitu menjadi manusia yang mampu menata diri dan menjawab berbagai tantangan baik dirinya sendiri maupun lingkungannya secara adaptif dan konstruktif. ${ }^{10}$ Kegiatan pengembangan diri santri di pesantren Hubulo dilakukan melalui kegiatan ekstrakurikuler.

Kegiatan ekstrakurikuler merupakan kegiatan yang dilakukan di luar kelas dengan tujuan membimbing peserta didik dalam mengembangkan potensi dan bakat yang ada dalam dirinya melalui kegiatan-kegiatan wajib maupun pilihan. ${ }^{11}$ Keberhasilan kegiatan ekstrakurikuler ditandai dengan kemampuan santri dalam mengukir prestasi-prestasi yang diraih dalam ajang-ajang perlombaan.Pembinaan kegiatan ekstrakurikuler di pesantren memberikan banyak manfaat terhadap santri. Oleh karena itu, keberhasilan kegiatan ekstrakurikuler sangat tergantung kepada efektifitas penyelenggaraan kegiatan tersebut. ${ }^{12}$

Journal EVALUASI, 1.1 (2017), 85

<https://doi.org/10.1017/CBO9781107415324.004>.

8 . Dkk Muhaimin, Pengembangan Kurikulum Tingkat Satuan Pendidikan (KTSP) Pada Sekolah Dan Madrasah (Jakarta: Rajawali Press, 2009).

${ }^{9}$ Hery Wibowo, Psikologi Untuk Pengembangan Diri (Jakarta: Widya Padjadjaran, 2010).

${ }^{10}$. Dkk Muhaimin, Pengembangan Kurikulum Tingkat Satuan Pendidikan KTSP Pada

Sekolah Dan Madrasah (Jakarta: Rajawali Press, 2009).

${ }^{11}$ Departemen Agama RI, Panduan Kegiatan Ekstrakurikuler (Jakarta: Direktorat Jenderal Pendidikan Departemen Agama RI, 2005).

12 Endin Mujahidin, Pesantren Kilat Alternatif Pendidikan Agama Luar Sekolah (Jakarta: Pustaka Al-Kautsar, 2005). 
EVALUASI, 4 (1), Maret 2020, ISSN 2580-3387 (print) |

ISSN 2615-2886 (online)

Homepage : http://e-journal.staima-alhikam.ac.id/index.php/evaluasi

DOI : : http://doi.org/10.32478/evaluasi.v4i1.358

Article type : Original Research Article

Kesuksesan pendidikan ekstrakurikuler berkaitan erat dengan kedisiplinan santri. Kedisiplinan santri merupakans uatu keadaan tertib dan teratur yang dimiliki oleh santri di pesantren, tanpa ada pelanggaranpelanggaran yang merugikan baik secara langsung maupun tidak langsung terhadap santri itu sendiri dan pesantren.Kedisiplinan santrimerupakan syarat utama dinamisnya pendidikan pesantren. Setiap pesantren memiliki visi dan misi tertentu untuk menghasilkan santri yang berkualitas. Oleh karena itu, setiap individu atau kelompok diupayakan agar mampu mencapai target yang telah ditentukan,sehingga penerapan disiplin santri dapat terbentuk menjadi sebuah sistem.Sistem yang diinginkan adalah segala sesuatu yang telah diagendakan pesantren dapat tercapai dan terlaksana dengan baik.

Berdasarkan hasil pengamatan, penerapan disiplin yang diterapkan di pesantren Hubulo membuat santri merasa terbebani oleh aturan, sehingga santri tidak mampu mengembangkan potensi dirinya dengan maksimal.Akibatnya, santri sering kalah bersaing dengan siswa sekolahsekolah yang bukan pesantren baik dalam bidang akademik maupun bidang non akademik.

Pengembangan diri santri yang tidak maksimal ditunjukkan melalui kegagalan-kegagalan yang dialami pada kegiatan-kegiatan lomba-lomba seperti Musabaqah Qira'atul Kutub, Musabaqah Tilawatil Qur'an, Aksioma, Olimpiade Sains Madrasah, Lomba Pidato Bahasa Arab dan Inggris, olah raga, seni dan lain sebagainya. Hal ini membuktikan bahwa, penerapan disiplin yang tidak disesuaikan dengan kondisi fisik maupun psikis santri akan berdampak negatif pada pengembangan diri santri itu sendiri.

\section{B. METODE PENELITIAN}

Jenis penelitian yang digunakan dalam penelitian kualitatif. Menurut Bogdan, penelitian kualitatif merupakan prosedur penelitian yang menghasilkan data deskriptif berupa ungkapan dari orang itu sendiri atau perilaku yang diamati. ${ }^{13} \mathrm{Hal}$ ini sejalan dengan apa yang kemukakan oleh Lexy J. Moleong, bahwa penelitian kualitatif adalah latar alamiah, manusia sebagai

${ }^{13}$ B. Robert \& Steven J. Tailor, Dasar-Dasar Penelitian Kualitatif (Surabaya: Usaha Nasional, 1993).

84 
EVALUASI, 4 (1), Maret 2020, ISSN 2580-3387 (print) I

ISSN 2615-2886 (online)

Homepage : http://e-journal.staima-alhikam.ac.id/index.php/evaluasi

DOI : : http://doi.org/10.32478/evaluasi.v4i1.358

Article type : Original Research Article

alat penelitian, analisa data secara induktif, teorinya dari dasar, dan bersifat deskriptif. ${ }^{14}$

Penelitian ini bertujuan untuk mendiskripsikan dan menganalisis data secara mendalam tentang penerapan disiplindan dampaknya terhadap pengembangan diri santri di pesantren Hubulo. Dengan sasaran yang akan dianalisis adalah proses penerapan disiplin dan dampak yang dihasilkan dari proses tersebut pada pengembangan diri santri.Penelitian naturalistik adalah menggunakan latar alamiah sebagai sumber data utama dan peneliti sebagai alat utama untuk mengumpulkan data kemudian ditafsirkan. ${ }^{15}$

Penelitian ini dilakukan di Desa Kramat Kecamatan Tapa Kabupaten Bone Bolango Provinsi Gorontalo, tepatnya di pesantren Hubulo. ${ }^{16} \mathrm{Hal}$ mendasar pengambilan lokasi ini adalah peneliti ingin memberikan kontribusi pemikiran dan informasi kepada masyarakat dengan menggali lebih dalam tentang penerapan disiplin yang diterapkan oleh pesantren Hubulo serta dampak dari penerapan disiplin terhadap pengembangan diri santri.Sumber data dalam penelitian ini dibagi menjadi 2, yaitu data primer dan data skunder. Data primer merupakan sumber yang langsung memberikan data kepada peneliti yang ditentukan secara sampling purposive (informan yang dipandang sangat mengetahui tentang masalah yang diteliti) berupa wawancara dengan pihak-pihak yang memiliki kaitan dengan permasalahan yang diteliti. Adapun pihak yang akan diwawancarai adalah pimpinan pesantren, wakil pimpinan I bidangkurikulum dan pengajaran, wakil pimpinan II bidangkesantrian, kepala madrasah aliyah, kepala madrasah tsanawiyah, ketua majelis pembina kesantrian, guru-guru yang memiliki hubungan langsung dengan penerapan disiplin dan pengembangan diri khususnya ekstrakurikuler, pengurus organisasi santri pesantren Hubulo dan santri.Data sekunder adalah sumber data yang tidak langsung memberikan data berupa dokumen-dokumen kepustakaan, kajian-kajian teori, karya ilmiah yang ada relevansinya dengan masalah yang diteliti yang berfungsi sebagai pelengkap data primer.Teknik pengumpulan data dilakukan untuk mencari bebagai informasi yang berhubungan dengan fokus penelitian. Adapun teknik yang dilakukan peneliti dalam memperoleh data adalah dengan observasi,

\footnotetext{
${ }^{14}$ Lexy J. Moleong, Metodologi Penelitian Kualitatif (Bandung: Rosdakarya, 2004).

${ }^{15}$ David Williams, Penelitian Naturalistik (Jakarta: Fakultas Pascasarjana IKIP Jakarta, 1989).

16 'Pesantren Hubulo' <http://hubulo.com/>.
} 
EVALUASI, 4 (1), Maret 2020, ISSN 2580-3387 (print) |

ISSN 2615-2886 (online)

Homepage : http://e-journal.staima-alhikam.ac.id/index.php/evaluasi

DOI : : http://doi.org/10.32478/evaluasi.v4i1.358

Article type : Original Research Article

wawancara sampling purposive, dan dokumentasi. Sampling purposive bertujuan untuk menghimpun data dan informasi sebanyak mungkin sampai pada titik jenuh dengan menggunakan teknik bertujuan untuk menghimpun data dan informasi sebanyak mungkin sampai pada titik jenuh dengan menggunakan teknik bertujuan untuk menghimpun data dan informasi sebanyak mungkin sampai pada titik jenuh dengan menggunakan teknik bola salju (snow ball). Artinya, suatu data atau informasi yang dijaring dari berbagai informan dan menunjukkan pernyataan yang sama, maka penjaringan data tersebut sudah dapat diakhiri.

\section{HASIL DAN PEMBAHASAN}

\section{Penerapan Disiplin dan Pengembangan Diri Santri di Pesantren Hubulo.}

\section{a. Penerapan Disiplin Santri di Pesantren Hubulo.}

Ppenerapan disiplin santri di pesantren Hubulo dititikberatkan pada tiga tempat, yaitu sekolah, asrama dan masjid. Disiplin di sekolah merupakan implementasi dari disiplin belajar, di asrama merupakan implementasi disiplin waktu, dan di masjid merupakan implementasi dari disiplin ibadah.

Tabel 1

Penerapan Disiplin Santri di Sekolah

1. Santri datang ke sekolah tepat waktu;

2. Santri mengikuti apel pagi dan memperhatikan arahan guru yang memberikan apel;

06.45-07.00

3. Santri membaca ibadah amaliah;

4. Santri menggunakan kelengkapan seragam sekolah sesuai peraturan;

5. Santri yang terlambat menjalankan sanksi dengan penuh tanggung jawab;

6. Santri menjaga kerapian dan kebersihan pakaian sesuai dengan peraturan sekolah;

7. Apabila santri berhalangan hadir ke sekolah maka santri menyertakan surat pemberitahuan ke sekolah;

8. Santri mengikuti keseluruhan proses pembelajaran dengan baik 
EVALUASI, 4 (1), Maret 2020, ISSN 2580-3387 (print) |

ISSN 2615-2886 (online)

Homepage : http://e-journal.staima-alhikam.ac.id/index.php/evaluasi

DOI $\quad$ : http://doi.org/10.32478/evaluasi.v4i1.358

Article type : Original Research Article

dan aktif;

9. Santri melaksanakan tugas piket kelas sesuai jadwal yang ditentukan;

10. Santri mengerjakan tugas yang diberikan guru;

11. Santri mengerjakan tugas yang diberikan guru;

12. Mengakhiri kegiatan belajar dan pulang sesuai jadwal yang 14.00 ditentukan; dan

13. Mengikuti kegiatan ekstakurikuler .

$16.00-17.00$

Santri yang memenuhi kriteria di atas, maka santri tersebut adalah santri yang disiplin.

Tabel 2

Penerapan Disiplin Santri di Asrama

\section{No} IndikatorDisiplin

\section{Waktu}

03.30

1. Santri bangun persiapan sholat subuh;

04.00 sholat subuh berjamaah;

3. Santri melaksanakan piket kamar ;

4. Santri sarapan pagi dan mengambil uang jajan di petugas asrama yang ditunjuk;

5. Santri keluar asrama pergi ke sekolah tepat waktu;

06.30

6. Santri menggunakan bahasa bahasa Inggris dalam percakapan sehari-hari;

7. Santri menggunakan bahasa Arab dalam percakapan seharihari;

8. Santri kembali masuk asrama (pulang sekolah);

9. Santri makan siang dan istirahat;

10. Santri melaksanakan sholat asar berjamaah di masjid;

11. Santri mengambil baju bersih dan mengantar baju kotor ke 16.00-17.00 loundri pesantren; 
EVALUASI, 4 (1), Maret 2020, ISSN 2580-3387 (print) I

ISSN 2615-2886 (online)

Homepage : http://e-journal.staima-alhikam.ac.id/index.php/evaluasi

DOI : : http://doi.org/10.32478/evaluasi.v4i1.358

Article type : Original Research Article

12. Santri mengerjakan piket asrama;

13. Santri melaksanakan shalat maghrib dan isya berjamaah di $17.30-20.00$ masjid;

14. Santri mengikuti kegiatan mahkamah santri;

15. Santri makan malam;

16. Santri belajar mandiri/ kelompok;

17. Santri mengikuti mufrodat/vocabulary;

18. Santri mengikuti apel malam dan istirahat.

Santri yang memenuhi kriteria di atas dengan baik dan tepat waktu, maka santri tersebut adalah santri yang disiplin.

Tabel 3

Penerapan Disiplin Santri di Masjid

No IndikatorDisiplin

Waktu

1 Santri mengerjakan piket masjid;

16.00-17.00

2 Santri datang di masjid 15 menit sebelum adzan shalat;

17.45-18.00

3 Santri mengatur sandal masing-masing dengan rapi;

4 Santri memakai pakaian shalat yang telah ditentukan untuk

$18.00-05.00$ shalat maghrib, isya' dan subuh (untuk putra memakai songkok nasional, baju putih, sarung hitam/putih) dan putri memakai mukena warna putih;

5 Santri mengerjakan sholat sunnah rawatib;

6 Santri membaca dzikir setelah shalat;

7 Santri membaca al-qur'an setelah shalat;

8 Santri menyetor ibadah amaliah;

9 Santri mengikuti kegiatan pembinaan santri; dan

10 Santri mengikuti muhadatsah/public speaking setelah shalat subuh.

04.45-05.00 
EVALUASI, 4 (1), Maret 2020, ISSN 2580-3387 (print) |

ISSN 2615-2886 (online)

Homepage : http://e-journal.staima-alhikam.ac.id/index.php/evaluasi

DOI : : http://doi.org/10.32478/evaluasi.v4i1.358

Article type : Original Research Article

Santri yang memenuhi kriteria di atas dengan baik dan tepat waktu, maka santri tersebut adalah santri yang disiplin.

Penerapan disiplin santri di pesantren Hubulo diatur dalam buku peraturan harian santri yang biasa disebut buku PERHIASAN. Buku tersebut berisi aturan santri dalam menjalani kehidupan di pesantren Hubulo. Penerapan kedisiplinan santri diatur pada pasal 35 tentang pelanggaran dan sanksi sebagaimana tabel 8 di bawah ini.

\section{b. Pengembangan Diri Santri di Pesantren Hubulo.}

\section{1) Bentuk Pengembangan Diri Santri di Pesantren Hubulo}

Berdasarkan hasil pengamatan dan wawancara, bahwa kegiatan pengembangan diri santri di pesantren Hubulo adalah dalam bentuk ekstrakurikuler dengan rincian sebagai berikut:

Tabel 4

Kegiatan Pengembangan Diri / Kegiatan Ekstrakurikuler Santri di Pesantren Hubulo

No Kegiatan Pengembangan Diri

1 Pramuka

2 Muhadharah

3 Tilawah

4 Hadrah

$5 \quad$ Kaligrafi

6 Seni tari

7 Basket

8 Sepak bola

\section{Tempat}

Lapangan basket

Asrama dan masjid

Masjid

Masjid

Sanggar kaligrafi

Asrama

Lapangan Basket

Lapangan sepak bola

\section{Waktu}

Kamis: $13.00-15.00$

Kamis:

Sore: $16.00-17.00$

Malam: 20.00-21.30

Sabtu-minggu:

16.00-17.30

Senin-rabu:

16.00-17.00

Sabtu-rabu:

16.00-17.00

Sabtu-rabu:

16.00-17.00

Sabtu-rabu:

16.00-17.00

Sabtu-rabu:

16.00-17.00 
EVALUASI, 4 (1), Maret 2020, ISSN 2580-3387 (print) |

ISSN 2615-2886 (online)

Homepage : http://e-journal.staima-alhikam.ac.id/index.php/evaluasi

DOI : : http://doi.org/10.32478/evaluasi.v4i1.358

Article type : Original Research Article

9 Sepak takraw

10 Bola voli

11 Bulutangkis

12 Tenis meja

13 Silat

14 Pertanian

15 Peternakan

16 Pertukangan

17 Jahit menjahit/ tata busana

18 Tata boga

19 Percetakan/sablon
Lapangan takraw

Lapangan bola voli

Lapangan bulutangkis

Lapangan tenis meja

(asrama)

Lapangan dan teras

perpustakaan

Lahan pertanian

Kandang peternakan

Gudang

Konveksi

Dapur umum

Gudang
Sabtu-rabu:

16.00-17.00

Sabtu-rabu:

16.00-17.00

Sabtu-rabu:

16.00-17.00

Sabtu-rabu:

16.00-17.00

Sabtu-rabu:

16.00-17.00

Sabtu-rabu:

16.00-17.00

Sabtu-rabu:

16.00-17.00

Sabtu-rabu:

16.00-17.00

Sabtu-rabu:

16.00-17.00

Sabtu-rabu:

16.00-17.00

Sabtu-rabu:

16.00-17.00

\section{a)Pramuka}

Kegiatan pramuka di pesantren Hubulo merupakan kegiatan wajib yang harus diikuti oleh setiap santri. Kegiatan pramuka dilaksanakan setiap hari kamis pukul 13.00 Wita sampai dengan pukul 15.00 Wita. Kegiatan pramuka di pesantren Hubulo bertujuan untuk membentuk pribadi santri yang disiplin, terampil dan mandiri. Pelaksana harian santri dibimbing oleh pengurus bindep yang telah dilatih dan memenuhi persyaratan untuk melatih adik-adiknya dengan didampingi guru pelatih pramuka. Guru pembimbing pramuka saat ini adalah ustadz ahmad fauzi.

Kegiatan pramuka di pesantren Hubulo bekerjasama dengan kwartir, kwarcab dan kwarda provinsi Gorontalo. Dengan adanya kerjasama dengan pihak-pihak tersebut, maka santri yang berprestasi dalam mengikuti kompetisi dalam ajang daerah dan nasional. Oleh karena itu, kegiatan pramuka di pesantren Hubulo merupakan wadah santri untuk mengembangkan potensi dirinya, sebab santri mendapatkan pengajaran 
EVALUASI, 4 (1), Maret 2020, ISSN 2580-3387 (print) |

ISSN 2615-2886 (online)

Homepage : http://e-journal.staima-alhikam.ac.id/index.php/evaluasi

DOI : : http://doi.org/10.32478/evaluasi.v4i1.358

Article type : Original Research Article

keterampilan dan kedisiplinan. Selain itu, kegiatan pramuka merupakan tempat untuk melepas lelah, karena santri telah disibukkan dengan kegiatan pesantren dari sekolah, asrama dan masjid yang begitu padat dan penuh kedisiplinan. ${ }^{17}$

\section{b) Muhadharah}

Muhadharah adalah kegiatan keterampilan berbicara di tempat umum berupa pidato tiga bahasa yaitu pidato bahasa arab, bahasa inggris dan bahasa indonesia. Tujuan kegiatan muhadharah adalah melatih santri untuk terampil dalam menyampaikan pidato/ceramah dengan maksud mengajak bukan menggurui, sehingga orang yang diajak berkomunikasi mengerti maksud yang dibicarakan. Fungsinya utama kegiatan muhadharah adalah membangun mental santri agar berani percaya diri dan tidak minder.

Kegiatan muhadharah dilaksanakan setiap hari kamis malam jum'at setelah makan malam. Akan tetapi sekarang ini kegiatan muhadharah dilakukan pada sore hari untuk pembinaan rutin dan malam hari dijadikan sebagai kegiatan muhadharah kubra dan lomba muhadharah. Kegiatan muhadharah ini dibimbing langsung oleh pengurus organisasi santri pesantren Hubulo bagian bahasa yang didampingi langsung oleh guru-guru asrama. Pembimbing kegiatan muhadharah sekarang ini adalah ustadzah siti mawadah zainal abidin, S.Th.I, ustadzah siti i'anah, ustadz yaser faisal, ustadz syamsul hadi, ustadz fauzi, ustadz adin musthofa Lc., M.Pd, dan ustadz ikromi, S.HI. Dengan bimbingan yang berkesinambungan, maka diharapkan santri mampu berdakwah dengan baik maupun dapat mengukir prestasi dalam ajang perlombaan pidato tingkat daerah dan nasional. ${ }^{18}$

\section{c) Tilawah}

Tilawah adalah kegiatan keterampilan dalam membaca al-qur'an dengan menggunakan lagu sesuai kaidah-kaidah tertentu. Tujuan dari pembelajaran tilawah adalah diharapkan santri dapat membaca al-qur'an dengan baik dan benar serta dapat melantunkan ayat-ayat suci al-qur'an dengan lagu dan suara yang merdu. Selain itu tujuan kegiatan tilawah adalah agar santri mampu berkompetisi dalam ajang musabaqah tilawatil qur'an baik tingkat daerah maupun tingkat nasional.

\footnotetext{
${ }^{17}$ Hasil wawancara dengan ketua Majelis Pembina Kesantrian Pesantren Hubulo, Ali Sabana Mudakir, M.Pd

${ }^{18}$ Hasil wawancara dengan, Ketua Majelis Pembina Kesantrian Pesantren Hubulo; Ali Sabana Mudakir, M.Pd
} 
EVALUASI, 4 (1), Maret 2020, ISSN 2580-3387 (print) |

ISSN 2615-2886 (online)

Homepage : http://e-journal.staima-alhikam.ac.id/index.php/evaluasi

DOI : : http://doi.org/10.32478/evaluasi.v4i1.358

Article type : Original Research Article

Kegiatan tilawah ini merupakan kegiatan ekstrakurikuler pilihan, sehingga pesertanya adalah terbatas pada santri yang mau mengikutinya saja. Kegiatan tilawah ini dilaksanakan di masjid al hidayah pesantren Hubulo dengan waktu pelaksanaan pada pukul 16.00 Wita sampai dengan pukul 17.30 Wita. Guru pembimbing tilawah saat ini adalah ustadz qasim musa alumni lembaga tilawatil qu'ran bandung. ${ }^{19}$

d) Hadrah.

Hadrah adalah kegiatan keterampilan seni memainkan music rebana. Kegiatan ini bertujuan untuk melatih santri terampil memainkan alat music rebana yang merupakan ciri khas musik Islami.

Kegiatan hadrah di pesantren Hubulo merupakan kegiatan ekstrakurikuler pilihan yang dilaksanakan di masjid pada pukul 16.00 Wita sampai dengan 17.00 Wita. Santri yang sudah mahir dalam memainkan alat hadrah, maka santri tersebut akan ditunjuk untuk memainkan alat rebana tersebut dalam mengiringi bacaan asmaul husna yang dilaksanakan setiap setelah shalat isya, bahkan diutus untuk mengikuti ajang perlombaan hadrah tingkat daerah dan nasional. Kegiatan hadrah ini dibimbing oleh kakak senior yang telah mahir dan didampingi langsung oleh pembimbing hadrah yang didatangkan langsung dari jakarta. Guru pembimbing hadrah ada dua orang yaitu ustadz septa berasal dari jakarta dan ustadz imam berasal dari bandung. 20

\section{e)Kaligrafi.}

Kaligrafi adalah kegiatan keterampilan seni menulis indah hurufhuruf arab, ayat-ayat al-qur'an, hadis, maupun mahfudzat. Kegiatan kaligrafi bertujuan untuk membentuk keterampilan anak dalam menulis indah hurufhuruf arab menjadi karya seni yang menarik. Kegiatan seni kaligrafi di pesantren Hubulo dibina langsung oleh ustadz amir ngau yang merupakan alumni dari lembaga kaligrafi nasional (lemka) jakarta.

Kegiatan seni kaligrafi ini dilaksanakan pada hari sabtu sampai dengan rabu pada pukul 16.00 sampai dengan pukul 17.00 Wita. Selain itu pelajaran seni kaligrafi ini juga diajarkan pada kegiatan belajar mengajar di madrasah tsanawiyah Hubulo dan madrasah aliyah Hubulo. Dengan

19 Hasil wawancara dengan Hasil wawancara dengan, Ketua Majelis Pembina Kesantrian Pesantren Hubulo; Ali Sabana Mudakir.

20 Hasil wawancara dengan Hasil wawancara dengan, Ketua Majelis Pembina Kesantrian Pesantren Hubulo; Ali Sabana Mudakir. 
EVALUASI, 4 (1), Maret 2020, ISSN 2580-3387 (print) |

ISSN 2615-2886 (online)

Homepage : http://e-journal.staima-alhikam.ac.id/index.php/evaluasi

DOI : : http://doi.org/10.32478/evaluasi.v4i1.358

Article type : Original Research Article

pembelajaran seni kaligrafi ini diharapkan santri akan semakin mencintai alqur'an dan mampu bersaing dalam ajang perlombaan seni kaligrafi tingkat daerah dan nasional. ${ }^{21}$

f) Tari.

Seni tari adalah kegiatan keterampilan dalam gerakan tubuh. Tujuan seni tari adalah mewadahi santri yang ingin berekspresi dalam bidang tari. Seni tari yang diterapkan di pesantren adalah tari saman. Sedangkan untuk seni tari free style tidak ditentukan secara khusus.

Kegiatan tari tari saman dilatih oleh pengurus bagian minat dan bakat. Sedangkan untuk free style dance santri dilatih oleh kakak kelas, atau mereka sendiri yang membentuk sebuah group tari. Kegiatan tari ini dilaksanakan setiap hari sabtu sampai dengan rabu pada pukul 16.00 sampai dengan pukul 17.00 Wita. Kegiatan tari ini bersifat sebagai ajang unjuk diri kesenangan saja dan sebagai pengisi acara hiburan dalam setiap kegiatan pentas seni yang tidak di kategorikan dalam perlombaan. ${ }^{22}$

g)Basket.

Basket adalah kegiatan olah raga bola tangan. Tujuan olah raga ini adalah untuk melatih kedisiplinan, kerjasama, dan menjaga kesehatan jasmani. Kegiatan olah raga ini di pesantren Hubulo dilaksanakan di lapangan basket yang merupakan lapangan milik pesantren.

Kegiatan olah raga basket di pesantren Hubulo dilaksanakan setiap hari sabtu sampai dengan hari rabu pukul 16.00 Wita sampai dengan pukul 17.00 Wita. Kegiatan olah raga basket di pesantren Hubulo dilatih oleh guru pendidikan jasmani dan kesehatan. Akan tetapi pada prosesnya santri sering berlatih sendiri tanpa didampingi oleh pelatih. Dengan adanya kegiatan olah raga basket diharapkan santri mampu bersaing dalam kompetisi basket tingkat daerah dan nasional. ${ }^{23}$

h) Sepak Bola.

Sepak bola adalah kegiatan olah raga bermain bola kaki. Tujuan olah raga ini adalah untuk melatih kedisiplinan, kerjasama, dan menjaga kesehatan jasmani. Kegiatan olah raga sepak bola di pesantren Hubulo

${ }^{21}$ Hasil wawancara dengan Ketua Majelis Pembina Kesantrian Pesantren Hubulo Ali Sabana Mudakir, M.Pd

${ }^{22}$ Hasil wawancara dengan ketua Majelis Pembina Kesantrian Pesantren Hubulo, Ali Sabana Mudakir, M.Pd

${ }^{23}$ Hasil wawancara dengan ketua Majelis Pembina Kesantrian Pesantren Hubulo, Ali Sabana Mudakir, M.Pd Sabana Mudakir, M.Pd. 
EVALUASI, 4 (1), Maret 2020, ISSN 2580-3387 (print) |

ISSN 2615-2886 (online)

Homepage : http://e-journal.staima-alhikam.ac.id/index.php/evaluasi

DOI : : http://doi.org/10.32478/evaluasi.v4i1.358

Article type : Original Research Article

dilaksanakan di lapangan sepak bola yang merupakan lapangan milik pesantren.

Kegiatan olah raga sepak bola di pesantren Hubulo dilaksanakan setiap hari sabtu, senin, selasa dan rabu pukul 16.00 Wita sampai dengan pukul 17.00 Wita. Hari minggu dan hari jum'at santri tidak diperkenankan bermain olah raga sepak bola karena pada hari tersebut merupakan hari kunjungan santri dan lapangan sepak bola tersebut menjadi area parkir kendaraan para orang tua santri. Kegiatan olah raga sepak bola di pesantren Hubulo dilatih oleh guru pendidikan jasmani dan kesehatan. Akan tetapi pada prosesnya santri sering berlatih sendiri tanpa didampingi oleh pelatih. Dengan adanya kegiatan olah raga sepak bola, diharapkan santri mampu bersaing dalam kompetisi sepak bola khususnya liga santri nasional. ${ }^{24}$

\section{i) Sepak Takraw.}

Sepak takraw adalah kegiatan olah raga bermain bola kaki khusus yang terbuat dari rotan atau plastic khusus. Tujuan olah raga ini adalah untuk melatih kedisiplinan, kerjasama, dan menjaga kesehatan jasmani. Kegiatan olah raga sepak takraw di pesantren Hubulo dilaksanakan di lapangan sepak takraw yang merupakan lapangan milik pesantren.

Kegiatan olah raga sepak takraw di pesantren Hubulo dilaksanakan setiap hari sabtu sampai dengan hari rabu pukul 16.00 Wita sampai dengan pukul 17.00 Wita. Kegiatan olah raga sepak takraw di pesantren Hubulo dilatih oleh guru pendidikan jasmani dan kesehatan. Akan tetapi pada prosesnya santri sering berlatih sendiri tanpa didampingi oleh pelatih. Dengan adanya kegiatan olah raga sepak takraw, diharapkan santri mampu bersaing dalam kompetisi sepak takraw tingkat daerah dan nasional. ${ }^{25}$

\section{j) Bola Voli.}

Bola voli adalah kegiatan olah raga bermain bola tangan. Tujuan olah raga ini adalah untuk melatih kedisiplinan, kerjasama, dan menjaga kesehatan jasmani. Kegiatan olah raga bola voli di pesantren Hubulo dilaksanakan di lapangan sepak bola voli yang merupakan lapangan milik pesantren.

${ }^{24}$ Hasil wawancara dengan ketua Majelis Pembina Kesantrian Pesantren Hubulo, Ali Sabana Mudakir, M.Pd.

${ }^{25}$ Hasil wawancara dengan ketua Majelis Pembina Kesantrian Pesantren Hubulo, Ali Sabana Mudakir, M.Pd. 
EVALUASI, 4 (1), Maret 2020, ISSN 2580-3387 (print) |

ISSN 2615-2886 (online)

Homepage : http://e-journal.staima-alhikam.ac.id/index.php/evaluasi

DOI : : http://doi.org/10.32478/evaluasi.v4i1.358

Article type : Original Research Article

Kegiatan olah raga sepak takraw di pesantren Hubulo dilaksanakan setiap hari sabtu sampai dengan hari rabu pukul 16.00 Wita sampai dengan pukul 17.00 Wita. Kegiatan olah raga sepak takraw di pesantren Hubulo dilatih oleh guru pendidikan jasmani dan kesehatan. Akan tetapi pada prosesnya santri sering berlatih sendiri tanpa didampingi oleh pelatih. Dengan adanya kegiatan olah raga bola voli, diharapkan santri mampu bersaing dalam kompetisi bola voli tingkat daerah dan nasional. ${ }^{26}$

\section{k)Bulutangkis.}

Bulutangkis adalah kegiatan olah raga bermain bola khusus yang terbuat dari bulu dan kayu yang dirancang khusus yang biasa disebut cock. Tujuan olah raga ini adalah untuk melatih kedisiplinan, kerjasama, dan menjaga kesehatan jasmani. Kegiatan olah raga bulutangkis di pesantren Hubulo dilaksanakan di lapangan bulutangkis yang merupakan lapangan milik pesantren.

Kegiatan olah raga bulutangkis di pesantren Hubulo dilaksanakan setiap hari sabtu sampai dengan hari rabu pukul 16.00 Wita sampai dengan pukul 17.00 Wita. Kegiatan olah raga bulutangkis di pesantren Hubulo dilatih oleh guru pendidikan jasmani dan kesehatan. Akan tetapi pada prosesnya santri sering berlatih sendiri tanpa didampingi oleh pelatih. Dengan adanya kegiatan olah raga bulutangkis, diharapkan santri mampu bersaing dalam kompetisi bulutangkis tingkat daerah dan nasional. ${ }^{27}$

\section{I) Tenis Meja.}

Tenis meja adalah kegiatan olah raga bermain bola khusus sebesar telur ayam yang terbuat plastik khusus dengan lapangan terbuat dari kayu berbentuk meja lebar yang dilengkapi dengan net pembatas. Tujuan olah raga ini adalah untuk melatih kedisiplinan, kerjasama, dan menjaga kesehatan jasmani. Kegiatan olah raga tenis meja di pesantren Hubulo dilaksanakan di lapangan sendiri yang merupakan lapangan milik pesantren.

Kegiatan olah raga tenis meja di pesantren Hubulo dilaksanakan setiap hari sabtu sampai dengan hari rabu pukul 16.00 Wita sampai dengan pukul 17.00 Wita. Kegiatan olah raga tenis meja di pesantren Hubulo dilatih oleh guru pendidikan jasmani dan kesehatan. Akan tetapi pada prosesnya

${ }^{26}$ Hasil wawancara dengan ketua Majelis Pembina Kesantrian Pesantren Hubulo, Ali Sabana Mudakir, M.Pd.

${ }^{27}$ Hasil wawancara dengan Ketua Majelis Pembina Kesantrian Pesantren Hubulo Ali Sabana Mudakir, M.Pd 
EVALUASI, 4 (1), Maret 2020, ISSN 2580-3387 (print) |

ISSN 2615-2886 (online)

Homepage : http://e-journal.staima-alhikam.ac.id/index.php/evaluasi

DOI : : http://doi.org/10.32478/evaluasi.v4i1.358

Article type : Original Research Article

santri sering berlatih sendiri tanpa didampingi oleh pelatih. Dengan adanya kegiatan olah raga tenis meja, diharapkan santri mampu bersaing dalam kompetisi tenis meja tingkat daerah dan nasional. ${ }^{28}$

m) Silat.

Silat adalah kegiatan seni bela diri. Tujuan olah raga ini adalah untuk melatih kedisiplinan, kerjasama, dan menjaga kesehatan jasmani. Kegiatan seni bela diri di pesantren Hubulo dilaksanakan di teras pesantren Hubulo.

Kegiatan seni bela diri di pesantren Hubulo dilaksanakan setiap hari jum'at sampai dengan hari rabu pukul 16.00 Wita sampai dengan pukul 17.00 Wita. Kegiatan seni bela diri silat di pesantren Hubulo dilatih oleh guru silat khusus dengan aliran tapak suci. Akan tetapi pada latihan santri didampingi oleh pelatih. Dengan adanya kegiatan seni beladiri silat, diharapkan santri mampu menjaga diri, lebih percaya diri dan bersaing dalam kompetisi silat tingkat daerah dan nasional. ${ }^{29}$

\section{n) Pertanian.}

Pertanian adalah kegiatan pengembangan diri bercocok tanam. Tujuan kegiatan pertanian ini adalah agar santri terampil dan mengerti bagaimana cara bercocok tanam yang baik dan santri lebih menghargai hasil jerih payah para petani, sehingga santri menjadi tumbuh rasa peka dan peduli terhadap orang lain.

Kegiatan pertanian di pesantren Hubulo dibina langsung oleh ustadz Abd. Roziq yang bekerja sama dengan dinas pertanian dan peternakan provinsi Gorontalo. Dalam kegiatan ini santri diajarkan bagaimana cara bertani yang benar, sehingga ketika santri pulang ke kampong halaman dapat mempraktekkan ilmu pertanian tersebut di kampung halaman. Kegiatan pertanian saat ini masih berhenti dikarenakan jadwal santri sudah padat, sehingga untuk kegiatan pertanian saat ini diserahkan dan dikelola oleh karyawan pesantren Hubulo. ${ }^{30}$

${ }^{28}$ Hasil wawancara dengan Ketua Majelis Pembina Kesantrian Pesantren Hubulo; Ali Sabana Mudakir, M.Pd

${ }^{29}$ Hasil wawancara dengan ketua Majelis Pembina Kesantrian Pesantren Hubulo Ali Sabana Mudakir, M.Pd.

${ }^{30}$ Hasil wawancara dengan ketua Majelis Pembina Kesantrian Pesantren Hubulo Ali Sabana Mudakir, M.Pd. 
EVALUASI, 4 (1), Maret 2020, ISSN 2580-3387 (print) |

ISSN 2615-2886 (online)

Homepage : http://e-journal.staima-alhikam.ac.id/index.php/evaluasi

DOI : : http://doi.org/10.32478/evaluasi.v4i1.358

Article type : Original Research Article

\section{o) Peternakan.}

Peternakan adalah kegiatan pengembangan diri dalam berternak. Tujuan kegiatan peternakan ini adalah agar santri terampil dan mengerti bagaimana cara berternak yang baik dan menumbuhkan rasa peka dan peduli terhadap orang lain.

Kegiatan peternakan di pesantren Hubulo dibina langsung oleh ustadz Abd. Roziq yang bekerja sama dengan dinas pertanian dan peternakan provinsi Gorontalo. Dalam kegiatan ini santri diajarkan bagaimana cara berternak yang benar, sehingga ketika santri pulang ke kampong halaman dapat mempraktekkan ilmu peternakan tersebut di kampung halaman. Kegiatan peternakan saat ini masih berhenti dikarenakan jadwal santri sudah padat, sehingga untuk kegiatan peternakan saat ini diserahkan dan dikelola oleh karyawan pesantren Hubulo. ${ }^{31}$

p) Pertukangan.

Pertukangan adalah kegiatan pengembangan diri dalam bentuk pengolahan kayu. Tujuan kegiatan pertukangan ini adalah agar santri terampil cara mengolah kayu menjadi bermanfaat.

Kegiatan pertukangan di pesantren Hubulo dibina langsung oleh ustadz Abd. Roziq. Dalam kegiatan ini santri diajarkan bagaimana cara mengolah kayu menjadi lebih bermanfaat, sehingga ketika santri pulang ke kampung halaman dapat mempraktekkan ilmu pertukangan tersebut di kampung halaman. Tempat pelaksanaan adalah di gudang pesantren. Adapun waktu pelaksanaanya dilaksanakan pada hari sabtu sampai dengan hari rabu pukul 16.00 Wita sampai dengan pukul 17.00 Wita. Dengan pembelajaran pertukangan ini diharapkan santri tidak hanya pintar di dalam bidang keagamaan dan akademik sekolah, tetapi juga mahir dalam bidang keterampilan. ${ }^{32}$

\section{q) Menjahit.}

Menjahit adalah kegiatan pengembangan diri dalam bentuk jahit menjahit. Tujuan kegiatan pertukangan ini adalah agar santri terampil dalam bidang jahit menjahit.

\footnotetext{
${ }^{31}$ Hasil wawancara dengan ketua Majelis Pembina Kesantrian Pesantren Hubulo Ali Sabana Mudakir, M.Pd.

${ }^{32}$ Hasil wawancara dengan ketua Majelis Pembina Kesantrian Pesantren Hubulo Ali Sabana Mudakir, M.Pd.
} 
EVALUASI, 4 (1), Maret 2020, ISSN 2580-3387 (print) |

ISSN 2615-2886 (online)

Homepage : http://e-journal.staima-alhikam.ac.id/index.php/evaluasi

DOI : : http://doi.org/10.32478/evaluasi.v4i1.358

Article type : Original Research Article

Kegiatan jahit menjahit di pesantren Hubulo dibina langsung oleh bagian konveksi pesantren Hubulo. Dalam kegiatan ini santri diajarkan bagaimana cara menjahit dan membuat pakaian, sehingga ketika santri pulang ke kampung halaman dapat mempraktekkan ilmu jahit menjahit tersebut di kampung halaman. Tempat pelaksanaan adalah di gedung konveksi pesantren. Adapun waktu pelaksanaanya dilaksanakan pada hari sabtu sampai dengan hari rabu pukul 16.00 Wita sampai dengan pukul 17.00 Wita. Dengan pembelajaran jahit menjahit ini diharapkan santri memiliki bekal keteampilan dalam bidang menjahit. ${ }^{33}$

r) Tata Boga.

Tata Boga adalah kegiatan pengembangan diri dalam bentuk memasak. Tujuan kegiatan tata boga ini adalah agar santri terampil dalam bidang masak memasak.

Kegiatan tata boga di pesantren Hubulo dibina langsung oleh bagian dapur pesantren Hubulo. Dalam kegiatan ini santri diajarkan bagaimana cara memasak nasi, sayur dan membuat kue, sehingga ketika santri pulang ke kampung halaman dapat mempraktekkan ilmu tersebut di kampung halaman. Tempat pelaksanaan adalah di gedung dapur umum pesantren. Adapun waktu pelaksanaanya dilaksanakan pada hari sabtu sampai dengan hari rabu pukul 16.00 Wita sampai dengan pukul 17.00 Wita. Dengan pembelajaran tata boga ini diharapkan santri memiliki bekal keterampilan dalam bidang masak-memasak. ${ }^{34}$

\section{s) Percetakan (Sablon).}

Sablon adalah kegiatan pengembangan diri dalam bentuk percetakan. Tujuan kegiatan ini adalah agar santri terampil dalam bidang percetakan.

Kegiatan sablon di pesantren Hubulo dibina langsung oleh ustdz Abd. Roziq. Dalam kegiatan ini santri diajarkan bagaimana cara menyablon, sehingga ketika santri pulang ke kampung halaman dapat mempraktekkan ilmu tersebut di kampung halaman. Tempat pelaksanaan adalah di gudang pesantren. Adapun waktu pelaksanaanya dilaksanakan pada hari sabtu sampai dengan hari rabu pukul 16.00 Wita sampai dengan pukul 17.00 Wita.

\footnotetext{
${ }^{33}$ Hasil wawancara dengan ketua Majelis Pembina Kesantrian Pesantren Hubulo Ali Sabana Mudakir, M.Pd.

${ }^{34}$ Hasil wawancara dengan ketua Majelis Pembina Kesantrian Pesantren Hubulo Ali Sabana Mudakir, M.Pd.
} 
EVALUASI, 4 (1), Maret 2020, ISSN 2580-3387 (print) |

ISSN 2615-2886 (online)

Homepage : http://e-journal.staima-alhikam.ac.id/index.php/evaluasi

DOI : : http://doi.org/10.32478/evaluasi.v4i1.358

Article type : Original Research Article

Dengan pembelajaran sablon ini diharapkan santri memiliki bekal keteampilan dalam bidang percetakan. ${ }^{35}$

Untuk saat ini kegiatan pengembangan diri yang sudah pernah berjalan akan tetapi berhenti sementara adalah pertanian, peternakan, pertukangan, dan percetakan (sablon). Kegiatan tersebut tidak berjalan karena belum tersedianya tenaga pembimbing yang ahli dalam bidang tersebut. $^{36}$

\section{Dampak Penerapan Disiplin Terhadap Pengembangan Diri Santri Pesantren Hubulo.}

Penerapan disiplin santri di pesantren Hubulo sekarang ini bisa dikatakan pada level tinggi. Oleh sebab itu, banyak orang tua santri lama dan santri baru yang mengeluh dengan sistem kedisiplinan di pesantren Hubulo. Kedisiplinan yang diterapkan di pesantren Hubulo bertujuan untuk mewujudkan visi dan misi pesantren Hubulo. Dalam mewujudkan visi dan misi pesantren Hubulo, maka diperlukan kedisiplinan yang tinggi. Dengan penerapan disiplin yang tinggi diharapkan visi dan misi pesantren dapat tercapai dengan sempurna.

Penerapan disiplin santri bukanlah sekedar untuk memenuhi kebutuhan pesantren, melainkan untuk memenuhi harapan santri agar dapat menimba ilmu yang banyak serta memperoleh manfaat dari apa yang telah dipelajarinya selama di pesantren. Oleh sebab itu, penerapan disiplin diharapkan mampu memupuk semangat santri dalam mengembangkan potensi dirinya,sehingga santri menjadi pintar dalam bidang akademik dan mahir dalam bidang pengembangan diri (ekstrakurikuler).

Berdasarkan hasil penelitian, ditemukan berbagai macam persepsi dan sudut pandang dalam mendefinisikan, memahami tujuan, langkah yang seharusnya diterapkan dalam kegiatan penerapan kedisiplinan santri. Perbedaan pandangan tersebut menunjukkan bahwa setiap orang mempunyai sudut pandang berbeda dalam memahami kedisiplinan santri.

Sebagian besar informan memberikan keterangan yang intinya sama tentang kedisiplinan santri. Kedisiplinan santri didefinisikan sebagai kepatuhan dan ketaatan santri terhadap aturan yang telah disepakati

${ }^{35}$ Hasil wawancara dengan ketua Majelis Pembina Kesantrian Pesantren Hubulo Ali Sabana Mudakir, M.Pd.

${ }^{36}$ Hasil wawancara dengan ketua Majelis Pembina Kesantrian Pesantren Hubulo Ali Sabana Mudakir, M.Pd. 
EVALUASI, 4 (1), Maret 2020, ISSN 2580-3387 (print) |

ISSN 2615-2886 (online)

Homepage : http://e-journal.staima-alhikam.ac.id/index.php/evaluasi

DOI : : http://doi.org/10.32478/evaluasi.v4i1.358

Article type : Original Research Article

bersama dan dilaksanakan dengan rasa penuh tanggung jawab, apabila dilanggar akan dikenakan sanksi. Artinya santri dikatakan berdisiplin apabila ia mematuhi dan menaati aturan yang berlaku dan siap menerima sanksi ketika melakukan pelanggaran.

Keberadaan disiplin sangatlah penting dan dibutuhkan dalam kehidupan santri. Tanpa adanya kedisiplinan, santri akan cenderung hidup sembarangan dan bermalas-malasan, sehingga akan membawa dampak yang tidak baik pada diri santri itu sendiri. Oleh karena itu, apabila santri ingin meraih kesuksesan, maka santri harus menanamkan kedisiplinan pada dirinya.

Penerapan kedisiplinan santri di pesantren sudah diatur dengan baik. Peraturan yang mengatur tentang kedisiplinan santri terbagi menjadi dua yaitu peraturan kehidupan harian santri yang biasa disingkat dengan perhiasan dan tengko mahkamah santri. Peraturan tersebut disosialisasikan secara lisan dan tulisan yang terangkum dalam sebuah buku dan diberikan kepada masing-masing santri. Buku peraturan disiplin diberikan pada saat santri pada awal masuk pesantren Hubulo. Sedangkan tengko dibacakan pada saat santri sudah masuk ke dalam pesantren Hubulo.

Buku perhiasan adalah buku yang mengatur kehidupan santri selama menjadi santri di pesantren Hubulo. Penerapan buku perhiasan dijalankan oleh majelis Pembina kesantrian. Sedangkan tengko adalah peraturan yang mengatur kedisiplinan santri dalam menjalani kehidupan sehari-hari di dalam asrama. Penerapan tengko dijalankan oleh organisasi santri pesantren Hubulo melalui kegiatan mahkamah santri.

Mahkamah santri adalah majelis pengadilan yang berwenang mengadili santri yang melakukan pelanggaran terhadap aturan dan tata tertib pesantren. Kewenangannya adalah memutuskan hukuman yang bersifat pelanggaran ringan dengan tujuan edukatif. Perbedaan antara perhiasan dengan tengko adalah terletak pada kekuatan putusan hukumnya. Perhiasan menangani pelanggaran santri dalam kategori sedang sampai kategori berat, sehingga putusan perhiasan lebih tinggi karena memiliki kewenangan untuk menjatuhkan skorsing dan mengeluarkan santri. Sedangkan putusan tengko hanya bersifat kontrol dan edukatif, sehingga putusannya berkisar pada perbaikan santri, akan tetapi tidak memiliki wewenang untuk menjatuhkan skorsing maupun mengeluarkan santri.

Kedisiplinan santri yang diterapkan di pesantren Hubulo memiliki tujuan yang jelas. $\mathrm{H}$. Abd hakim selaku wakil pimpinan wakil pimpinan I yang 
EVALUASI, 4 (1), Maret 2020, ISSN 2580-3387 (print) |

ISSN 2615-2886 (online)

Homepage : http://e-journal.staima-alhikam.ac.id/index.php/evaluasi

DOI : : http://doi.org/10.32478/evaluasi.v4i1.358

Article type : Original Research Article

membidangi bagian kurikulum dan pengajaran menjelaskan bahwa tujuan penerapan kedisiplinan santri di pesantren Hubulo adalah membentuk mental santri yang tangguh dan mandiri. Pernyataan tersebut didukung oleh $\mathrm{H}$. Abdul roziq selaku wakil pimpinan II yang membidangi bagian kesantrian yang menyatakan bahwa tujuan kedisiplinan santri adalah melatih santri untuk melakukan kebiasaan-kebiasaan yang baik serta membentuk pribadi santri yang penuh percaya diri. Melihat kedua pernyataan tersebut, hal ini menggambarkan bahwa kedisiplinan santri memiliki peranan penting dalam membentuk individu menjadi pribadi yang unggul sehingga dapat mengantarkan santri meraih kesuksesan belajar dan kelak ketika sudah bergelut dalam dunia pekerjaan.

Kedisiplinan santri merupakan unsur penting dalam menjalani kehidupan di pesantren. Prakteknya, penerapan kedisiplinan santri di pesantren Hubulo tidaklah mudah. Oleh karena itu, perlu adanya langkahlangkah yang tepat untuk mencapai tujuan kedisiplinan santri tersebut.

Langkah-langkah dalam upaya menerapkan kedisiplinan santri dijelaskan oleh $\mathrm{Hj}$. Rachmayanti monoarfa selaku pimpinan pesantren Hubulo bahwa penerapan kedisiplinan santri di pesantren Hubulo harus dilakukan dengan membangun sistem yang kuat dengan melibatkan seluruh individu pesantren yang terdiri dari pimpinan, guru-guru, santri dan orang tua santri. Langkah berikutnya adalah membuat buku petunjuk aturan untuk santri yang tertuang dalam buku peraturan santri. Buku tersebut menjadi pegangan santri dan penegak aturan pesantren. Buku tersebut digunakan untuk menindaklanjuti pelanggaran santri dalam kategori sedang dan berat. Sedangkan untuk penegakan disiplin dalam kehidupan sehari-hari, santri di atur melalui mahkamah santri. Oleh karena itu, langkahyang tepat untuk meningkatkan kedisiplinan santri di pesantren Hubulo adalah melakukan evaluasi terhadap kesiapan diri dalam melaksanakan tugas dan tanggung jawab yang diberikan.

Pernyataan tersebut didukung oleh H. Abd. Hakim selaku wakil pimpinan I bidang kurikulum pesantren Hubulo, beliau menambahkan tentang langkah-langkah yang harus dilakukan dalam menerapkan kedisiplinan santri di pesantren Hubulo yaitu dengan memberikan pemahaman yang benar tentang kedisiplinan, sosialisasi yang berkesinambungan, mengadakan pelatihan-pelatihan kepemimpinan dan praktek kedisiplinan santri melalui organisasi santri yang ada di pesantren Hubulo. Penerapan kedisiplinan santri memerlukan dukungan pihak yang 
EVALUASI, 4 (1), Maret 2020, ISSN 2580-3387 (print) |

ISSN 2615-2886 (online)

Homepage : http://e-journal.staima-alhikam.ac.id/index.php/evaluasi

DOI : : http://doi.org/10.32478/evaluasi.v4i1.358

Article type : Original Research Article

bertanggung jawab dalam pelaksanaan kedisiplinan santri. Pihak yang bertanggung jawab adalah seluruh civitas akademika pesantren Hubulo yang terdiri dari pimpinan, sekolah, asrama, dan pengurus organisasi santri pesantren Hubulo. Peran pimpinan adalah memberikan kepercayaan kepada bagian kesantrian untuk menjalankan aturan yang tercantum dalam perhiasandengan cara memberikan hukuman bagi yang tidak disiplin dan memberikan penghargaan bagi yang patuh terhadap aturan. Peran sekolah adalah sama dengan peran pimpinan. Peran asrama dalam penerapan disiplin adalah dengan memberikan contoh dan keteladanan yang baik. Sedangkan peran pengurus organisasi santri pesantren Hubulo adalah berpartisipasi aktif serta menjadi teladan bagi santri lainnya dengan memegang teguh prinsip siap dipimpin dan memimpin.

Dalam usaha meningkatkan kedisiplinan santri, maka yang harus dilakukan adalah adanya satu komando mulai dari pimpinan sampai kepada pengurus organisasi santri pesantren Hubulo, tidak membuat aturan di atas aturan yang sudah ada, serta menjadi penggerak yang berwibawa dan bijaksana, yang dicintai dan bukan ditakuti.

Pernyataan di atas juga didukung oleh Moh. Arya selaku ketua organisasi santri pesantren Hubulo putra, menjelaskan langkah-langkah yang seharusnya dilakukan dalam menerapkan kedisiplinan santri di pesantren Hubulo adalah dengan pengenalan peraturan kehidupan santri (perhiasan), melalui organisasi santri yang telah dibekali dengan latihandasar kepemimpinan dan menjadikan guru sebagai teladan yang memiliki kewibawaan dan kebijaksanaan. Adapun pihak yang bertanggung jawab dalam penerapan kedisiplinan santri adalah dewan pimpinan, majelis pembina kesantrian, komisi disiplin, organisasi santri dan santri itu sendiri. Peran pimpinan adalah menjadi teladan dan sosok yang berwibawa dan tegas. Meninggalkan pemikiran yang kolot dan kaku, sehingga dalam penegakkan disiplin dapat menunjukkan sikap yang loyal.

Peran sekolah adalah menjadikan santri sebagai orang yang berjiwa terdidik, sehingga pikiran santri terbuka dan menjadi peka. Peran asrama dalam menegakkan kedisiplinan santri seharusnya mempunyai sebagai orang tua yang mengajarkan anak-anaknya perasaan hadir dalam ketenangan. Peran pengurus organisasi adalah sebagai subjek terdepan untuk memberikan peringatan dalam menegakkan kedisiplinan dengan tetap berpikir jernih dengan selalu mengingatkan santri agar senantiasa berdisiplin. Pengurus harus bisa menjadi teladan bagi santri lainnya, sebab santri yang 
EVALUASI, 4 (1), Maret 2020, ISSN 2580-3387 (print) |

ISSN 2615-2886 (online)

Homepage : http://e-journal.staima-alhikam.ac.id/index.php/evaluasi

DOI : : http://doi.org/10.32478/evaluasi.v4i1.358

Article type : Original Research Article

dipilih menjadi pengurus adalah orang-orang yang memiliki potensi lebih dibanding dengan santrilainnya, baik dibidang akademik maupun tingkah laku. Dalam penerapan disiplin santri sebaiknya dimulai dari diri sendiri kemudian mendisiplinkan orang lain dengan prinsip sami'na wa atha'na.

Pernyataan di atas juga didukung oleh Zahirah ginggani alam selaku ketua organisasi pesantren Hubulo putri menjelaskan langkah-langkah yang seharusnya dilakukan dalam menerapkan kedisiplinan santri di pesantren Hubulo. Tahapan yang harus dilakukan adalah membangkitkan kesadaran diri dari para santri akan pentingnya kedisiplinan, adanya perhatian dari para ustadz dan ustadzah dalam penegakkan kedisiplinan serta perhatian para pengurus terutama ketika berada di asrama. Adapun pihak yang bertanggung jawab dalam penerapan kedisiplinan santri adalah para santri itu sendiri beserta pengurus yang membantu kedisiplinan serta adanya dukungan dari ustadz dan ustadzah dan juga kerjasama dari orang tua santri.

Pimpinan berperan mengontrol atau memantau jalannya kedisiplinan santri serta memberikan contoh-contoh kedisiplinan, baik pada santri maupun guru. Peran guru disekolah dalam penerapan kedisiplinan santri adalah membantu jalannya peraturan kedisiplinan yang telah ditetapkan pada aturan pesantrenagar peraturan kedisiplinan yang diterapkan kepada santri dapat berjalan sebagaimana mestinya. Peran asrama dalam menegakkan kedisiplinan harus tegas, akan tetapi asrama tetap memberikan pendidikan serta pembinaan akan pentingnya kedisiplinan bagi kehidupan santri, dan asrama tetap menciptakan suasana kekeluargaan yang hangat.

Peran pengurus sebagai penegak kedisiplinan adalah membantu para ustadz dan ustadzah yaitu dengan memberikan teladan yang baik bagi santri lainnya, kemudian tegas dalam menegakkan peraturan kedisiplinan. Oleh karena itu, untuk meningkatkan kedisiplinan santri di pesantren Hubulo, maka kegiatan ini harus didukung oleh semua elemen yang ada di pesantren Hubulo mulai dari santri, organisasi santri pesantren Hubulo, guru-guru dan unsur pimpinan.

Hasil capaian penerapan kedisiplinan santri di pesantren berdasarkan hasil penelitian memiliki dua jawaban yang berbeda. Satu sisi mengatakan bahwa penerapan kedisiplinan santri sudah sesuai dengan apa yang diinginkan, akan tetapi disisi lain mengatakan bahwa penerapan kedisiplinan santri di pesantren Hubulo belum sesuai dengan apa yang diinginkan. 
EVALUASI, 4 (1), Maret 2020, ISSN 2580-3387 (print) |

ISSN 2615-2886 (online)

Homepage : http://e-journal.staima-alhikam.ac.id/index.php/evaluasi

DOI : : http://doi.org/10.32478/evaluasi.v4i1.358

Article type : Original Research Article

Hasil penelitian yang menyatakan bahwa kedisiplinan santri telah sesuai dengan apa yang diinginkan pesantren adalah pernyataan $\mathrm{Hj}$. Rachmayanti monoarfa yang menyatakan bahwa penerapan kedisiplinan santri di pesantren sudah sesuai dengan apa yang diinginkan, akan tetapi dalam pelaksanaanya masih bersifat fluktuatif sehingga penerapan kedisiplinan santri di pesantren Hubulo belum bisa dikatakan sepenuhnya berhasil.

Pernyataan tersebut juga didukung oleh Ikromi, S.HI, selaku kepala MA. Hubulo, bahwa penerapan kedisiplinan santri sudah sesuai dengan apa yang diinginkan terutama santri putri, sedangkan untuk santri putra masih perlu ditingkatkan lagi terutama pengurus organisasi santri pesantren Hubulo, karena mereka adalah penggerak kedisiplinan itu sendiri.

Pernyataan tersebut juga didukung oleh Hikmah Juwita Ayub guru bahasa Inggris, bahwa penerapan kedisiplinan santri telah sesuai dengan tujuan yang diinginkan pesantren. Contohnya karakter santri yang mandiri yang taat dan patuh, sehingga bedampak pada moralitas santri yang terbentuk menjadi santri yang saleh dan berakhlak baik. Hal ini terjadi karena adanya situasi yang kondusif dan penerapan aturan yang merata.

Hasil penelitian yang menyatakan bahwa kedisiplinan santri belum sesuai dengan apa yang diinginkan adalah pernyataan yang disampaikan oleh H. Abd. Hakim selaku wakil pimpinan I bidang kurikulum dan pengajaran, bahwa penerapan kedisiplinan santri belum sesuai dengan apa yang diinginkan karena mutu sumber daya manusianyamasih rendah dan tidak kompeten dalam bidangnya, sehingga kesadaran akan disiplin belum terbangun.

Pernyataan tersebut juga didukung oleh Hayratih podungge guru mata pelajaran bahasa Arab MTs. Hubulo, beliau juga menyatakan bahwa pada umumnya penerapan disiplin santri di pesantren Hubulo belum sepenuhnya berhasil, karena pada prakteknya masih terdapat toleransi yang kurang obyektif terhadap para pelanggar aturan yang disebabkan oleh pihakpihak yang selalu membuat disiplin tidak berjalan dengan semestinya.

Pernyataan ini juga didukung oleh Siti i'anah guru asrama pesantren Hubulo yang menyatakan bahwa penegakkan disiplin santri di pesantren Hubulo belum sepenuhnya berhasil karena kurangnya kerjasama antar guru, orang tua dan pihak asrama khususnya dalam hal informasi. Seharusnya dalam penerapan kedisiplinan santri seluruh personil yang ada di pesantren terutama guru harus bekerjasama dengan murid dalam membangun, 
EVALUASI, 4 (1), Maret 2020, ISSN 2580-3387 (print) |

ISSN 2615-2886 (online)

Homepage : http://e-journal.staima-alhikam.ac.id/index.php/evaluasi

DOI $\quad$ : http://doi.org/10.32478/evaluasi.v4i1.358

Article type : Original Research Article

memelihara dan memperbaiki aturan-aturan pesantren. Ketika memutuskan suatu aturan maka harus dikomunikasikan kepada seluruh pihak agar merata, sehingga tidak ada yang saling menyalahkan satu sama lain. Oleh karena itu keterlibatan guru harus lebih ditingkatkan lagi dalam penerapan kedisiplinan santri, baik guru dalam maupun guru luar.

Pernyataan tersebut juga didukung oleh Moh. Arya selaku santri sekaligus ketua organisasi santri pesantren Hubulo putra pesantren Hubulo bahwa penerapan kedisiplinan di pesantren Hubulo belum sesuai dengan apa yang diinginkan karena guru yang tinggal di dalam lingkungan pesantren kurang menampakkan kedewasaan dalam menerapkan kedisiplinan santri. Selain itu kurangnya perhatian dan kecakapan guru dalam menindaklanjuti pelanggaran yang dilakukan santri.

Pernyataan tersebut juga didukung oleh Zahirah ginggani alam selaku santri sekaligus ketua organisasi santri pesantren Hubulo putri pesantren Hubulo, bahwa penerapan kedisiplinan santri di pesantren Hubulo masih belum berhasil sepenuhnya, buktinya adalahmasih banyaknya para pelanggar kedisiplinan di pesantren Hubuloserta kurangnya kerjasama dari orang tua santri yang belum memiliki kesadaran akan pentingnya kedisiplinan.

Dari pernyataan-pernyataan di atas menunjukkan bahwa cara pandang setiap orang dalam memahami kedisiplinan itu berbeda dan memiliki standar yang berbeda pula. Sehingga dalam memahami kedisiplinan ada yang berpendapat bahwa kedisiplinan sudah sesuai dengan ada pula yang berpendapat bahwa kedisiplinan belum sesuai. Oleh karena itu, untuk memahami dan mengukur apakah tujuan kedisiplinan santri sudah sesuai dengan apa yang diinginkan oleh pesantren, maka harus diukur dengan hasil yang dicapai sesuai dengan visi dan misi pesantren Hubulo.

Untuk mencapai hasil yang sempurna $100 \%$ itu agak sulit, akan tetapi untuk ukuran keberhasilannya bisa diukur dengan memberikan batasan capaian minimal $80 \%$ bahwa aturan telah dijalankan. Apabila capaian mencapai $80 \%$, maka kedisiplinan santri bisa dikatakan berhasil.

Dalam penerapan disiplin di pesantren Hubulo terdapat faktor pendukung dan faktor penghambat. Faktor pendukung penerapan disiplin di pesantren Hubulo adalah sebagai berikut:

1. Adanya sistem yang sudah tertata rapi;

2. Adanya evaluasi berkala yang bertujuan untuk meningkatkan kualitas kedisiplinan santri; 
EVALUASI, 4 (1), Maret 2020, ISSN 2580-3387 (print) |

ISSN 2615-2886 (online)

Homepage : http://e-journal.staima-alhikam.ac.id/index.php/evaluasi

DOI : : http://doi.org/10.32478/evaluasi.v4i1.358

Article type : Original Research Article

3. Adanya buku statuta untuk para guru dan karyawan;

4. Adanya buku perhiasan untuk santri;

5. Adanya pengurus organisasi santri pesantren hubulo (organisasi santri pesantren hubulo) sebagai motor penggerak dalam setiap kegiatan;

6. Adanya hukuman yang dapat membuat efek jera terhadap pelanggar disiplin;

7. Adanya kerja sama dengan guru-guru di asrama dan guru di sekolah yang didukung oleh kinerja para pengurus organisasi santri pesantren Hubulo; dan

Sedangkan faktor penghambat penerapan disiplin santri di pesantren Hubulo adalah sebagai berikut:

1. Mutu sumber daya manusia yang rendah dan tidak kompeten dalam bidangnya;

2. Seringnya terjadi missundertanding atau kesalahpahaman dalam memaknai kedisiplinan santri yang disebabkan oleh kurangnya koordinasi antara guru satu dengan guru yang lain;

3. Kurangnya kesadaran disiplin serta belum siapnya pribadi untuk dipimpin dan memimpin;

4. Adanya oknum-oknum yang senantiasa membuat penerapan disiplin tidak berjalan;

5. Kurangnya istiqamah dalam menjalankan pengontrolan;

6. Adanya Egoisme guru dan karyawan yang tidak taat aturan;

7. Guru yang tinggal di dalam lingkungan pesantren yang kurang menampakkan kedewasaan dalam menerapkan kedisiplinan;

8. Adanya sikap orang tua yang kurang memahami tujuan penegakkan disiplin; dan

9. Kurangnya kerjasama dari orang tua santri yang belum memiliki kesadaran pentingnya kedisiplinan.

Berdasarkan hasil penelitian, guna meningkatkan kedisiplinan santri di pesantren Hubulo, informan banyak memberikan masukan-masukan dan solusi yang beragam. Mereka berharap dengan adanya masukan tersebut dapat menjadikan pesantren Hubulo lebih baik lagi dan kedisiplinan santri menjadi lebih baik dari sebelumnya. Adapun solusi guna meningkatkan kedisiplinan santri adalah dengan menumbuhkan kesadaran diri, pembinaan 
EVALUASI, 4 (1), Maret 2020, ISSN 2580-3387 (print) |

ISSN 2615-2886 (online)

Homepage : http://e-journal.staima-alhikam.ac.id/index.php/evaluasi

DOI : : http://doi.org/10.32478/evaluasi.v4i1.358

Article type : Original Research Article

secara terus menerus dan istiqamah, serta adanya keteladanan dari seluruh civitas akademika pesantren Hubulo.

Selanjutnya adalah pengembangan diri santri di pesantren Hubulo. Hasil penelitian menunjukkan beragamnya cara pandang dalam memahami tentang pengembangan diri, langkah-langkah dalam pengembangan diri sampai pada solusi yang ditawarkan dalam meningkatkan pengembangan diri.

H. Abd. Hakim(wakil pimpinan I bidang kurikulum dan pengajaran) mendefinisikan pengembangan diri santri adalah cara atau proses perubahan diri santri secara bertahap ke arah yang lebih baik. H. Abdul roziq (wakil pimpinan II bidang kesantrian) mendefinisikan pengembangan diri adalah mengembangkan dan mengelola bakat dan kemampuan santri.

Amir ngau (guru kaligrafi pesantren Hubulo) mendefinisikan pengembangan diri adalah kegiatan yang dilakukan oleh santri di luar kegiatan belajar mengajar di sekolah guna memperdalam keahlian santri dalam bidang tertentu. Moh. Arya (ketua organisasi santri pesantren Hubulo putra) mendefinisikan pengembangan diri santri adalah peningkatan diri yang dilakukan untuk menguasai ajaran agama dengan iman, Islam dan ihsan secara benar dan istiqamah, dan zahirah ginggani alam (ketua organisasi santri pesantren Hubulo putri) mendefinisikan pengembangan diri adalah usaha atau kegiatan yang dapat mengembangkan dan meningkatkan kualitas santri yang baik serta potensi bakat-bakat yang ada pada diri santri.

Definisi tersebut menjelaskan bahwa pengembangan diri itu berkaitan erat dengan minat, bakat, potensi dan keahlian santri.Untuk mengetahui potensi santri maka pesantren Hubulo harus menyediakan wadah kegiatan yang memiliki tujuan pada pengembangan diri santri. Oleh karena itu, pengembangan diri harus sesuai dengan kebutuhan santri dan mempunyai tujuan jangka pendek serta tujuan jangka panjang untuk masa depan santri.

Pengembangan diri santri memiliki tujuan untuk mengetahui perkembangan santri, keberhasilan belajar santri, wahana santri menggali dan mengekspresikan bakat dan minat meningkatkan kapasitas dan potensi santri dalam kegiatan ekstrakurikuler, menjadikan santri lebih terampil dan mandiri, meningkatkan kualitas diri santri dalam hal intelektual dan spiritual, sehingga santri termotivasi untuk selalu meningkatkan kualitas kepribadian santri kearah yang lebih baik. 
EVALUASI, 4 (1), Maret 2020, ISSN 2580-3387 (print) |

ISSN 2615-2886 (online)

Homepage : http://e-journal.staima-alhikam.ac.id/index.php/evaluasi

DOI : : http://doi.org/10.32478/evaluasi.v4i1.358

Article type : Original Research Article

Kegiatan pengembangan diri santri di pesantren Hubulo dikemas dalam bentuk ekstrakurikuler. Kegiatan ekstrakurikuler tersebut terbagi dalam dua kelompok. Kelompok pertama adalah kegiatan wajib dan kegiatan sunnah. Kegiatan wajib yaitu kegiatan ekstrakurikuler yang wajib diikuti oleh seluruh santri tanpa terkecuali, sedangkan ekstrakurikuler yang bersifat sunnah adalah kegiatan ekstrakurikuler yang bersifat pilihan tanpa ada paksaan.

Kegiatan ekstrakurikuler yang wajib di pesantren Hubulo adalah kegiatan pramuka dan muhadharah atau pidato tiga bahasa, yaitu bahasa Arab, bahasa Inggris, dan bahasa Indonesia. Adapun kegiatan ekstrakurikuler yang sunnah adalah selain pramuka dan muhadharah, yaitu olah raga (basket, sepak bola, sepak takraw, bulu tangkis, tenis meja, silat), seni (tilawah, hadrah/rebana/qasidah, kaligrafi, drama, dan tari), dan keterampilan (pertanian, peternakan, pertukangan, menjahit, tata boga/memasak, dan percetakan/sablon).

Di dalam kegiatan pengembangan diri santri di pesantren Hubulo terdapat faktor pendukung dan faktor penghambat. Faktor pendukung pengembangan diri santri di pesantren Hubulo adalah sebagai berikut:

1. Adanya dukungan pesantren;

2. Adanya pendanaan pembimbingan dan pelatihan dari pesantren;

3. Pemberian motivasi terhadap santri secara berkesinambungan dari pimpinan pesantren;

4. Tersedianya tenaga pengajar dan pelatih yang berpengalaman dibidangnya;

5. Minat dan bakat santri yang cukup beragam;

6. Adanya aturan yang dibuat oleh asrama dan pengurus organisasi santri pesantren hubulo; dan

7. Adanya dukungan dari guru-guru yang ada di lingkungan asrama.

Sedangkan faktor penghambat kegiatan pengembangan diri santri di pesantren Hubulo adalah sebagai berikut:

1. Sumber daya manusia yang tidak memadai;

2. Kurangnya kemauan dalam membina santri;

3. Kurangnya tenaga yang professional;

4. Sarana yang kurang memadai;

5. Tidak maksimalnya dalam menjalankan program;

6. Pendanaan yang belum maksimal; 
EVALUASI, 4 (1), Maret 2020, ISSN 2580-3387 (print) |

ISSN 2615-2886 (online)

Homepage : http://e-journal.staima-alhikam.ac.id/index.php/evaluasi

DOI : : http://doi.org/10.32478/evaluasi.v4i1.358

Article type : Original Research Article

7. Kurangnya perhatian pihak manajemen terhadap pembimbing atau pelatih;

8. Tidak adanya reward bagi pembimbing dan peserta yang telah meraih prestasi;

9. Kebijakan pimpinan dalam pemilihan pelatih yang tidak sesuai dan kurang kompeten;

10. Kurangnya minat santri terhadap kegiatan pengembangan diri;

11. Waktu yang pendek;

12. Banyak pilihan minat santri yang membuat santri tidak bisa menempatkan diri dan memilah dalam skala prioritas;

13. Kurangnya fokus tenaga pengajar yang mengajar pada kegiatan ekstrakurikuler;

14. Padatnya kegiatan wajib yang harus diselesaikan;

15. Masih terfokusnya pada penanganan santri yang bermasalah;

16. Masih kurangnya sarana pendukung yang dibutuhkan.

Hasil penelitian mengungkapkan bahwa dalam rangka meningkatkan pengembangan diri santri, maka diperlukan langkah-langkah yang tepat agar tujuan dari pengembangan diri santri dapat terwujud dengan baik. Adapun langkah-langkah yang dilakukan dalam meningkatkan pengembangan diri santri dalam bidang ekstrakurikuler adalah sebagai berikut:

1. Mengidentifikasi kecenderungan minat dan bakat santri;

2. Membuat angket tentang minat bakat;

3. Memilah santri yang memiliki bakat yang berbeda;

4. Menyusun program kegiatan;

5. Melakukan pelatihan dan pembinaan secara berkesinambungan;

6. Mendatangkan tenaga ahli yang sesuai dengan kebutuhan;

7. Melengkapisarana atau fasilitas yang dibutuhkan;

8. Melakukan monitoring;

9. Melakukan evaluasi; dan

10. Memberikan penghargaan bagi pembimbing dan santri yang berprestasi.

Berdasakan hasil penelitian, penerapan disiplin memiliki hubungan

erat dengan kegiatan pengembangan diri santri. Hasil penelitian menunjukkan bahwa penerapan kedisiplinan memberikan dampak positif 
EVALUASI, 4 (1), Maret 2020, ISSN 2580-3387 (print) |

ISSN 2615-2886 (online)

Homepage : http://e-journal.staima-alhikam.ac.id/index.php/evaluasi

DOI : : http://doi.org/10.32478/evaluasi.v4i1.358

Article type : Original Research Article

dan juga memiliki dampak negatif terhadap pengembangan diri santri. Akan tetapi dampak positifnya lebih besar dari pada dampak negatifnya.

Dampak positif yang dirasakan dari penerapan kedisiplinan santri adalah sebagai berikut:

1. Santri memiliki mental berani tampil dan percaya diri;

2. Menjadikan santri memiliki mental yang kuat dan lebih semangat dalam meraih apa yang dicita-citakan;

3. Pembimbingan bakat dan minat menjadi lebih maksimal;

4. Terbentuk nyaanak-anak yang patuh terhadap segala perintah dan larangan;

5. Santri mampu mandiri serta berkembang dalam segala hal sesuai dengan kemampuannya;

6. Akhlak dan prestasi santri lebih baik dari pada sebelumnya;

7. Ketika santri kembali ke masyarakat mereka dapat mengambil peran;

8. Santri mampu meningkatkan prestasi santri untuk menjadi lebih baik lagi; dan

9. Kegiatan ekstrakurikuler lebih terarah dan teratur, sehingga santri menjadi terdidik dan terlatih menjadi pribadi yang berkualitas, dan mampu menggali potensinyadalam bidang ekstrakurikuler.

Dampak negatif dari penerapan kedisiplinan terhadap pengembangan diri santri adalah sebagai berikut:

1. Kedisiplinan yang bersifat memaksa menimbulkan perasaan malas mengikuti kegiatan pengembangan diri; dan

2. Santri cenderung mudah frustasi sehingga kegiatan pengembangan diri tidak berjalan secara maksimal.

Penerapan disiplin santri di pesantren Hubulo belum mampu meningkatkan pengembangan diri santri. Hal ini terbukti dalam setiap kompetisi yang diikuti sering gagal menorehkan prestasi. Hal ini terjadi karena waktu yang pendek, dan santri terlalu banyak mengikuti kegiatan ekstrakurikuler, sehingga mereka tidak fokus terhadap salah satu kegiatan lomba. Akhirnya, mereka tidak matang dan mahir dalam setiap kegiatan yang diikuti dan mengakibatkan kekalahan dalam setiap perlombaan yang diikuti.

\section{KESIMPULAN}

Penerapan kedisiplinan santri di pesantren Hubulo sudah tertata dengan baik akan tetapi dalam pelaksanaannya memiliki kendala apabila tidak ada dukungan moril dari setiap elemen yang terkait dengan disiplin itu 
EVALUASI, 4 (1), Maret 2020, ISSN 2580-3387 (print) |

ISSN 2615-2886 (online)

Homepage : http://e-journal.staima-alhikam.ac.id/index.php/evaluasi

DOI : : http://doi.org/10.32478/evaluasi.v4i1.358

Article type : Original Research Article

sendiri, baik santri yang diusahakan untuk bisa disiplin dari awal masuk hinggaa menyelesaikan proses pendidikannya di pesantren. Penggerak disiplin, dalam hal ini pengurus organisasi pesantren Hubulo dan ustadustazah yang berada di pesantren Hubulo serta orang tua santri yahg bersedia dengan kedisiplinan pesantren itu sendiri.

Bentuk bentuk pengembangan diri santri dalam kegiatan ekstrakurikuler yang dilaksanakan adalah pramuka, tilawah, hadrah, basket, sepak bola, sepak takraw, bola voli, bulu tangkis, tenis meja, dan silat silat. Adapun kegiatan dan yang belum dilaksanakan adalah seni tari, pertaniaan, peternakan, pertukangan, jahit menjahit, tata boga, percetakan dan sablon.

Penerapan kedisiplinan memiliki dampak positif, yakni ketika santri mampu menaati aturan dengan baik sehingga bisa mengatur waktu dan bisa menyeimbangkan kewajiban di sekolah dan mengikuti kegiatan ekstrakurikuler yang dipilih, ada perubahan yang signifikan ketika santri sebelum masuk dan telah menjalani proses pendidikan di Pesantren Hubulo.

Penerapan kedisiplinan memiliki dampak negatif, ketika santri tidak siap dengan aktifitas wajib di asrama, sekolah, dan masjid. Santri cenderung malas dan frustasi ketika dipadatnya waktu dan tidak bisa mengembangkan potensi diri dan tidak dapat mengikuti kegiatan yang telah dipilih. Hal ini terbukti dalam setiap kompetisi yang diikuti sering gagal menorehkan prestasi.

Pada dasarnya penerapan disiplin di pesantren Hubulo cenderung memberikan dampak positif terhadap kehidupan santri dalam bidang pengembangan diri. Oleh karena itu, agar memberikan hasil yang baik terhadap pengembangan diri santri, maka yang harus dilakukan adalah:

1. Pesantren harus memberikan kebijakan waktu bagi santri yang dianggap penting untuk dibina khusus;

2. Nilai akademik dan ekstrakurikuler harus dipadukan sehingga santri yang memiliki bakat tertentu dan berprestasi di bidang ekstrakurikuler tidak merasa khawatir tidak naik kelas;

3. Mengurangi porsi beban belajar santri;

4. Aturan tidak boleh mematikan potensi diri santri dan setiap santri hanya memilih satu kegiatan pengembangan diri sesuai dengan minat dan bakatnya. 
EVALUASI, 4 (1), Maret 2020, ISSN 2580-3387 (print) |

ISSN 2615-2886 (online)

Homepage : http://e-journal.staima-alhikam.ac.id/index.php/evaluasi

DOI : : http://doi.org/10.32478/evaluasi.v4i1.358

Article type : Original Research Article

\section{DAFTAR PUSTAKA}

Ariesandi, Rahasia Mendidik Anak Agar Sukses Dan Bahagia (Jakarta: PT. Gramedia Utama, 2008)

B. Robert \& Steven J. Tailor, Dasar-Dasar Penelitian Kualitatif (Surabaya:

Usaha Nasional, 1993)

David Williams, Penelitian Naturalistik (Jakarta: Fakultas Pascasarjana IKIP Jakarta, 1989)

Dhofier, Zamakhsyari, Tradisi Pesantren: Studi Tentang Pandangan Kiai (Jakarta: LP3ES, 1982)

Ja'far, -, 'Problematika Pendidikan Pondok Pesantren Di Era Globalisasi', Journal EVALUASI, 2.1 (2018), 350 <https://doi.org/10.32478/evaluasi.v2i1.83>

Lexy J. Moleong, Metodologi Penelitian Kualitatif (Bandung: Rosdakarya, 2004)

Miftakhul Munir, 'MANAJEMEN PESANTREN DALAM MENINGKATKAN PENDIDIKAN AGAMA ISLAM DI PONDOK PESANTREN AL-AMIN NGASINAN REJOMULYO KEDIRI', Journal EVALUASI, 1.1 (2017), 85 <https://doi.org/10.1017/CBO9781107415324.004>

Muhaimin, . Dkk, Pengembangan Kurikulum Tingkat Satuan Pendidikan (KTSP) Pada Sekolah Dan Madrasah (Jakarta: Rajawali Press, 2009)

- - - , Pengembangan Kurikulum Tingkat Satuan Pendidikan KTSP Pada Sekolah Dan Madrasah (Jakarta: Rajawali Press, 2009)

Mujahidin, Endin, Pesantren Kilat Alternatif Pendidikan Agama Luar Sekolah (Jakarta: Pustaka Al-Kautsar, 2005)

'Pesantren Hubulo' <http://hubulo.com/>

RI, Departemen Agama, Panduan Kegiatan Ekstrakurikuler (Jakarta:

Direktorat Jenderal Pendidikan Departemen Agama RI, 2005)

- - , Pendidikan, Kumpulan Undang-Undang Dan Peraturan Pemerintah RI Tentang (Jakarta: Direktorat Jenderal Pendidikan Departemen Agama $\mathrm{RI}, 2006)$

Schaefer, Charles, Cara Efektif Mendidik Dan Mendisiplinkan Anak (Jakarta:

Mitra Utama, 1980)

Suharto, Edi, Membangun Masyarakat Memberdayakan Rakyat Kajian

Strategis Pembangunan Kesejahteraan Sosial Dan Pekerjaan Sosial 
EVALUASI, 4 (1), Maret 2020, ISSN 2580-3387 (print) |

ISSN 2615-2886 (online)

Homepage : http://e-journal.staima-alhikam.ac.id/index.php/evaluasi

DOI $\quad:$ http://doi.org/10.32478/evaluasi.v4i1.358

Article type : Original Research Article

(Bandung: PT Reflika Aditama, 2005)

Wibowo, Hery, Psikologi Untuk Pengembangan Diri (Jakarta: Widya

Padjadjaran, 2010) 